\title{
ACRL Budget Requests 1972/73
}

Line

Budget Actual Budget

Request Budget Request $1971 / 72 \quad 1971 / 72 \quad 1972 / 73$

Additional Staffing

1. Associate Executive Secretary

2. Secretary II

3. Professional Assistant (1/2 time)

Communications to Members

4. College \& Research Libraries

5. JCLS Communications Committee

Dissemination of Information

6. Materials for Advisory Service

$\$ 16,272 \$$

5,964

$\$ 16,272$

4,914

5,964

4,914

$(27,885) \quad(6,337) \quad$ (To be

$250 \quad 150 \begin{gathered}\text { determined } \\ 250\end{gathered}$

$\begin{array}{lll}700 & 630 & 700\end{array}$

Planning, Implementation and/or Evaluation of Activities

7. Commitee on Academic Status

8,160

8. ACRL Executive Committee

3,360

2,730

5,040

9. Committee on Standards \& Accreditation 3,000

10. AAJC/ALA (ACRL) Committee on Junior College Libraries

$1,850 \quad 1,490 \quad 1,850$

11. AAC/AAUP/ACRL Committee on College Libraries

$2,015 \quad 2,015 \quad 2,015$

12. ARL/ACRL Joint Committee on University Library Standards

13. NUEA/ACRL (ULS)

14. Cooperation with Educational and Professional Organizations

$2,100 \quad 2,100 \quad 2,100$

$1,230 \quad 1,230 \quad 1,230$

15. Subject Specialists Section

16. Art Subsection SSS

250

125

200

480

17. Rare Books \& Manuscripts Section

Preconference

$\begin{array}{llll}\text { Income } & 6,000 & 6,000 & 8,760 \\ \text { Expense } & \mathbf{4 , 7 7 0} & 4,770 & 7,460\end{array}$

18. Rare Books \& Manuscripts Section

420

19. University Libraries Section Preconference Income

Expense

20. Publications in Librarianship (formerly ACRL Monograph Ed. Bd.)

21. Oberly Memorial Award Committee

22. Slavic and East European Subsection Slavic Holdings Committee SSS

23. Representation to COSATI Meetings

New Requests

24. Ad Hoc Committee on Bibliographic Instruction

5. ACRL/JCLS Bibliographic Committee

$250 \quad 250 \quad 250$

$65 \quad 65 \quad 65$

$1,590 \quad 1,590$

$720 \quad 720 \quad 720$

etermined

To be

determined

26. ACRL Membership Promotion

For explanation of line items, see below.

Additional Staffing

I. Associate Executive Secretary-This person will report to the Exec- 
utive Secretary of ACRL and will carry out the charge established for the ACRL Academic Status Committee. He will investigate academic status problems in the field and will collect data necessary to achieve and maintain academic status. He will also coordinate and study all aspects of academic status including establishing relationships with appropriate academic bodies and associations. Appropriate equipment requested in General Funds.

2. Secretary II-Secretarial support for Associate Executive Secretary as requested in Line 1. Appropriate equipment requested in General Funds.

3. Half-time Professional Assistant-Difference between salary of fulltime Professional Assistant and that of the current salary $(\$ 4,914)$ of the present half-time Professional Assistant.

4. See budget requests for CRL (publications), which follows this section.

\section{Communications to Members}

5. To continue updating and distribution of the annual listing of twoyear College Libraries in the US and their administrative libraries.

To maintain a communications network for the purpose of exchanging ideas among the two-year Colleges.

For postage and long-distance phone calls.

\section{Dissemination of Information}

6. ACRL advisory materials consist largely of duplicated materials and of $C R L$ reprints of sufficient interest to warrant nominal production runs that would not fit into the cost/sale structure required by Publishing Services.

\section{Planning, Implementation and/or Evaluation of Activities}

7. Committee, established in June 1969, needs two meetings outside of the regular conference weeks in order to continue investigating academic status problems.

Transportation at $\$ 150$ each of ten committee members and ACRL Executive Secretary (eleven persons) to two meetings.

Per diem of $\$ 30.00$ for each of two days for each of eleven persons for each of two meetings.

To establish working relations with AAUP and AAC. Transportation at $\$ 150$ for Committee Chairman to Washington, D.C. for two meetings.

Per diem at $\$ 30.00$ for one person for each of two days for each of two meetings with AAUP and AAC.

$120 \frac{420}{\$ 5,040}$

8. Committee is concerned with the slowness of decision-making, the delay in putting decisions into activity, and the need for long-range planning within the division. It is felt that this group should have four regularly scheduled meetings outside of conference week, particularly during the next few years when reorganization is studied.

Transportation at $\$ 150$ for three committee members and the Executive Secretary (four persons) to each of four meetings.

Per diem at $\$ 30.00$ for each of two days for each of four persons for each of four meetings.

9. To continue to support the developing roles of this Committee in establishing direct communications with accrediting associations, it is proposed that the Chairman and the ACRL Executive Secretary schedule visits with the six regional accrediting associations. The objects of the visits would be as follows:

a. To work toward all six acerediting associations including a 
librarian on its visiting teams. At the present time, only the Southern Association follows this practice.

b. To build a solid basis of cooperation on all library problems related to accreditation between ACRL and the accrediting associations.

Contacting Accrediting Agencies-Transportation for six trips for two persons at $\$ 150$ for each per trip. $\$ 1,800$ Per diem at $\$ 30.00$ for each of three days for each of two persons for each of six trips.

College Standards Revision-Transportation for six people at $\$ 150$ each.

Per diem at $\$ 30.00$ for each of two days for six persons.

AECT Liaison-Transportation for two trips for three persons at $\$ 150$ each person.

Per diem at $\$ 30.00$ for each two days for each of two tips for each of three persons.

10. This committee, composed of Junior College Presidents and librarians, holds two meetings per year; one in conjunction with the ALA Annual Conference, and one in conjunction with the AAJC Annual Conference.

In 1972/73 the committee will continue to implement the Guidelines for Junior Colleges and pursue the problem of community use of Junior College Libraries.

Since the size of the committee has been reduced, only $\$ 1,850$ is being requested:

- Travel for the ACRL Executive Secretary to implement and facilitate the work of the joint committee. $\$$

- Transportation and per diem for four members of the committee and the Executive Secretary of ACRL to attend two meetings, to distribute literature for ALA, to provide library consultation service at the meetings.

- Miscellaneous expenses, postage, printing costs, telephone expenses, distribution of materials, etc.

11. At the time of regularly scheduled AAC activities, the joint committee holds two meetings a year, for which papers are prepared by knowledgeable academic librarians for publication in the committee's newsletter. This newsletter, published and distributed by AAC at its expense, is edited by an ACRL member. AAC through this committee is lending its support to the movement for academic status for librarians.

Postage for special mailing of "College Library Notes for the College President," to 3,500 members of College Library Section.

Transportation at $\$ 150$ for each of three committee members and the ACRL Executive Secretary (four persons) to each of two meetings annually.

Per diem at $\$ 30.00$ for each of two days for each of four persons at each of two meetings.

Travel to Washington to continue discussion between the ACRL Executive Secretary and the staff of AAC.

12. Joint Committee with ARL to work on revision of the new University Library Standards.

Transportation at $\$ 150$ for each of four ACRL committee members and the ACRL Executive Secretary (five persons) to each of two meetings designated by the chairman to work on university library standards. $\$ 1,500$

Per diem at $\$ 30.00$ for two days for each of five persons at each of two meetings. 
13. New joint committee presently in the organization stage. The committee will be composed of heads of extension departments at universities, and of librarians.

Transportation at $\$ 150$ for each of four ACRL committee members and the ACRL Executive Secretary (five persons) to annual meeting of NUEA.

Per diem at $\$ 30.00$ for each of five persons for each of two days and for each of two persons for an additional three days.

14. Not applicable.

15. $\$ 60.00$ for each Subsection Chairman and $\$ 60.00$ for the Section Chairman, above and beyond the standard $\$ 25.00$. This money would be in support of activities to strengthen the collective position of subject specialists as a professional group in academic libraries and in ALA. It will enable Subsection Chairmen to attend meetings of scholarly organizations in their respective subject fields which are attended by subject specialist librarians and to bring these librarians into ACRL as members.

Since subject specialists have two allegiances, namely, to their scholarly organizations and to their national library association, any reduction of their visibility in the latter will necessarily make them prone to dropping their ALA memberships.

16. During the last three or four years the ACRL Art SS has been revitalized due to its strong leadership, improved attempts to establish better communications and a small but active core of art librarians. For the well-being of the ACRL Art Subsection this core must be expanded by encouraging the active participation of the total Art SS membership. Institutional members should also be made aware of the Section's realistic, up-to-date goals and thus encouraged to become personal members. The growing interest in the College Art Association could weaken the Art Subsection position unless the above efforts are successful and some form of affiliation of the two groups is established.

The recent severe cuts in library budgets no longer allow individual institutions to subsidize the cost of their librarians' outside professional activities. Requested funds will be necessary for:

a. Clerical assistance, supplies, mailing costs, and telephone expenses.

b. Follow-up of the 1971/72 questionnaires.

c. Initial cost of compilation and mailing of lists of institutions wishing to take part in exchanges of duplicate serials. It will then be up to these institutions to send each other detailed duplicate and want lists.

d. Compilation and mailing of lists of completed or in progress research projects. There are numerous unpublished indexes and bibliographies which should be shared. This list will avoid unnecessary duplication of research and it is hoped will encourage individuals to take part in research which will be mutually beneficial.

e. Costs of organizing and then notifying membership of schedules for "mini" institutes or workshops which will be held during the Las Vegas Conference. These unofficial workshops will deal with various types of technical problems particular to art libraries such as cataloging of exhibition catalogs, collecting vertical file materials on local art, establishing cooperatives, etc. Experts in each area will be asked to serve as discussion leaders at no cost to ACRL. Also at no cost to ACRL, the four 
sessions will be held at two-hour intervals throughout the day in a suite reserved by the chairman. Sessions will be limited to $\$ 1.00$ per meeting to help cover the cost of the suite.

17. Preconference Institute on the subject of "People in the World of Special Collections."

18. Not applicable.

19. Preconference Institute on the subject of "The Place of the University Library in Regional Networks."

20. To be used by editor in securing manuscripts and to pay the clerical fees required to prepare a manuscript for publication.

21. Funds needed for general committee expense.

22. Not applicable.

23. To cover costs of the Executive Secretary to attend four COSATI meetings as Representative of ACRL.

Transportation at $\$ 150$ for each of four meetings. $\$ 600$

Per diem at $\$ 30.00$ for each of four trips.

24. A good deal of the work of the Committee is done by phone in order to help insure that the Committee's work is done expeditiously. Since the members of the Committee are widely separated geographically the phone expense will be sizeable. In addition, we have some expenses from 1971/72 that must be carried over into 1972/73 since the Committee was not established and operating until August 1971.

25. This committee is culminating a listing of the serials holdings of twoyear college libraries. The amount requested will enable the committee to duplicate the list in manuscript form and distribute it widely for correction and criticism, prior to its submission to ALA for possible publication.

\section{We've got them covered}

Between the covers of the new SWETS SUBSCRIPTION CATALOGUE 1972 we have brought together all those thousands of periodicals (14,000 actually) from all parts of the world now available through our Subscription Service. Copies are ready and waiting for you to send for one. At the same time, why not ask for details of the Subscription Service we offer? This new catalogue is just to whet your appetite for the more substantial benefits to follow.

Mail coupon below or call up either of our US branch offices for your copy

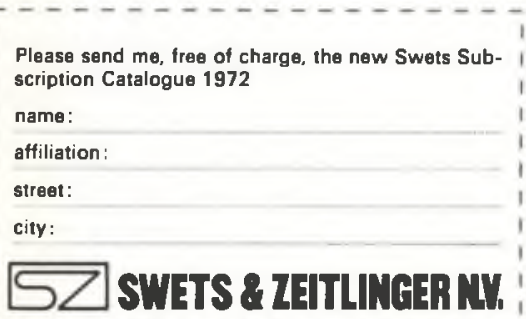

West Const office

Box 1761, SANTA CRUZ, Cal. 95060

Telephone: 408-426-2198

East Const office

Box 517, BERWYN, Pa. 19312

Telephone: 215-644-4944

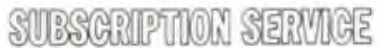

Keizersgracht 487 - Amsterdam - The Netherlands 